\title{
Self-service Technology for Hypermarket Checkout Stations
}

\author{
Hasliza Hassan ${ }^{1}$, Abu Bakar Sade ${ }^{2} \&$ Muhammad Sabbir Rahman ${ }^{3}$ \\ ${ }^{1}$ Faculty of Management, Multimedia University, Cyberjaya, Selangor, Malaysia \\ ${ }^{2}$ Global Entrepreneurship Research and Innovation Centre, Universiti Malaysia Kelantan, Kuala Lumpur, \\ Malaysia \\ ${ }^{3}$ Graduate School of Management, Multimedia University, Cyberjaya, Selangor, Malaysia \\ Correspondence: Hasliza Hassan, Faculty of Management, Multimedia University, Persiaran Multimedia, 63100 \\ Cyberjaya, Selangor, Malaysia. E-mail: hasliza.hassan@mmu.edu.my; liza.hassan@yahoo.com
}

Received: July 25, $2013 \quad$ Accepted: October 3, $2013 \quad$ Online Published: December 31, 2013
doi:10.5539/ass.v10n1p61
URL: http://dx.doi.org/10.5539/ass.v10n1p61

\begin{abstract}
The self-service technology innovation in hypermarket retailing has led to the shopping activity being served by the shopper themselves without relying on any service provider. However, this concept is still not implemented in Malaysia where the self-service concept is still supported by the service provider at the checkout station. This paper is suggesting that a new innovation should be implemented in the Malaysian hypermarket retailing industry by adopting self-service technology at the hypermarket checkout station. This research is developed based on observation conducted at various hypermarket retailing outlets within Malaysia. The findings from the general literature reviews are also gathered to strengthen the existing idea. The focus of this research is on the hypermarket retailing industry within Malaysia, especially in urban areas. Due to the modernization of the shopping trend, it is suggested that the timing might be right to explore implementing the concept of entirely self-service at hypermarkets in Malaysia to enhance the flow efficiency and effectiveness of the checkout operations. It is strongly believed that the introduction of this completely self-service shopping experience will be highly adopted, especially by the young generation in urban areas. This research explores the opportunity to enhance hypermarket retailing operations by upgrading the existing manual checkout station into self-service checkout stations using modern technology. It is expected that the idea for a totally self-service checkout system could be implemented in practice through the robust findings from this research.
\end{abstract}

Keywords: checkout, hypermarket, Malaysia, modern, retail, self-service, station, technology

\section{Introduction}

Hypermarket retailing is one of the modern retailing concepts that is widely accepted by most consumers, especially in urban and suburban areas. The wide variety of product choices and brands has become the main attraction for consumers to purchase basic necessities and household products from hypermarkets (Hassan \& Rahman, 2012). The uniqueness of this modern retailing concept is that the consumer is being forced to do all the shopping activities themselves by taking the trolley or basket, choosing the product from the shelves and bringing the products to the counter for payment. Consequently, the only place where there is any interaction between the consumer and the service provider is at the checkout station. Modern lifestyles that emphasize technology, have led to the need for the existing self-service hypermarket retailing concept to be upgraded to an entirely self-service concept by replacing the traditional cashiering operation with an automatic self-checkout station.

The checkout station is the only place where consumers are being fully served in hypermarkets. The lack of attention towards the consumers at the checkout station is almost equivalent to ignoring them in the earlier stages of the shopping activities. In line with this, a high level of satisfaction during the earlier stages might lead to higher expectations during the checkout stage. Most of the time, consumers will abandon the shopping cart if the checkout counter is inconvenient and does not meet expectations (Rajamma, Paswan \& Hossain, 2009), especially when the queue line is too long. Consequently, the checkout station is the most crucial spot in the hypermarket operations. Strong management skills are continuously required to avoid the checkout station from becoming a bottleneck in the overall hypermarket operations. Accordingly, the checkout station operation has yet to be transformed into a completely self-service hypermarket operation. 


\section{Issues at the Checkout Station}

\subsection{Cashier Workplace}

Cashiers might be the only service provider that consumers deal with when shopping at hypermarkets (Melachrinoudis \& Olafsson, 1995). The hypermarket cashier can handle between 500 to 1,000 items and fill more than 80 bags per hour (Sluchak, 1991). Cashiering activities are standardized and repetitive. The three main criteria for cashiers to receive consumers are: 1) anticipate the contact, 2) welcome the consumer, and 3) listen to the consumer's needs. The cashier should focus on two main elements while working: 1) productivity or product flow, and 2) service or consumer flow, which might lead to tension and contradiction. Cashiers also have to accelerate the pace of operation due to pressure from other consumers in the line. Usually, the pace at the checkout station is slower when the line is short (Bernard, 2007; Carrasco, Coleman \& Healey, 1995). The demand for faster, more efficient and better service at any hypermarket (Carrasco et al., 1995) has led to the nature of the checkout process being solely geared to speed and productivity.

The nature of the job of cashiers at the workstation might lead to postural problems (Rodacki, Vieira, Okimoto, Fowler \& Rodacki, 2006). The normal surfaces of workstations for cashiers are conveyor belt, scanner and bagging area (Shinnar, Indelicato, Altimari \& Shinnar, 2004). Cashiers have to work in a standing position in which they are repetitively moving products from the conveyor belt before scanning them and placing them in bags (Carrasco et al., 1995). The movement of cashiers to grasp the product from the conveyer belt, scan the bar code and deposit it in the packaging area will become riskier if the weight of the product is heavy (Rodacki et al., 2006). Cashiers have to handle many heavy products by lifting and dragging (Health and Safety Executive Books, 1998). Handling heavy products will definitely cause more stress then handling average or light products (Rodacki et al., 2006). The repetitive movement by the cashier can also cause them injury (Rodacki et al., 2006; Shinnar et al., 2004), which will have a negative impact on their job comfort, health and satisfaction. Cashiers can protest or demonstrate resistance by slowing down the work pace. The nature of work is also a common reason for the high turnover of cashiers (Diniz \& Ferreira, 1998).

\subsection{Waiting Time at Checkout Counter}

Consumers spend time when purchasing any type of product (Chetthamrongchai \& Davies, 2000). Consequently, most consumers would like to have flexibility in respect of time (Mantrala et al., 2009). While different consumers perceive time differently, time constraints lead consumers to be more concerned with the duration of the activity (Chetthamrongchai \& Davies, 2000). From the perspective of consumers, there are three components of waiting time: 1) selection time, 2) queue time, and 3) transaction time (Kumar, 2005). In hypermarket operations, $60 \%$ of the checkout operation involves three main time consuming tasks - scanning $(20 \%)$, packing $(18 \%)$ and payment transaction (22\%). One-fifth of the job time is accounted for by waiting to provide service to the consumers. Another $10 \%$ of the time is used for transferring bags (Carrasco et al., 1995). Consequently, the cost of service should be balanced with the cost of waiting (Zhao, Lau \& Lam, 2002).

\section{Self-service Technology at Checkout Stations}

An automatic self-checkout system involves the usage of highly integrated technology. Technology is the combination of knowledge, material, machinery, equipment, and work methods that allow an organization to transform inputs into outputs (Mascarenhas, Kesavan \& Bernacchi, 2004; Schermerhorn, 2002). Technology innovation could not occur in a vacuum without any environmental elements, such as demographic, social, lifestyle trends, economic, political and commercial development (Burt \& Sparks, 2003). Investment in technology does improve efficiency (Jamieson, 1996). Investment in flexible manufacturing technology within the Malaysian manufacturing industry, for example, has been proven to significantly improved productivity (Dolage, Sade \& Elsadig 2010). The technology for checkout stations keeps on changing (Health and Safety Executive Books, 1998). Modern technology, such as electric scanners at the checkout station (Jamieson, 1996; Larson \& Sijbrands, 1991) will definitely enhance existing checkout operations. From a review of the literature, Dean (2008) determined that the success of self-service technology is due to two factors: 1) reliability and 2) advantage (Meuter, Ostrom, Roundtree \& Bitner, 2000). Factors that influence the adoption and usage of self-service technology are 1) personal capacity, 2) perceived risk, 3) relative advantage, and 4) preference for personal contact (Walker \& Johnson, 2006).

Price scanning has been in existence in the retail industry for more than 20 years (Miranda, Konya \& Havrila, 2004). The usage of scanners at the checkout counter requires less skilled workers. The scanner at the checkout counter has made the cashier's job more standardized and allows hypermarkets to use non-skilled workers who they can train in a short period of time (Bernard, 2007). Accordingly, there is high possibility that the consumers can be trained how to checkout by themselves without continuously relying on the service provider. This 
automatic self-checkout system will persuade consumers to shop by themselves (Esbjerg \& Bech-Larsen, 2009). However, self-service technology requires high investment to set up and maintain. Thus, it is only cost effective if the hypermarket retailer can reduce the labour costs and capture a market segment (Dean, 2008). There is no benefit in upgrading a hypermarket's checkout system if the retailer is able to provide a quick checkout flow for the consumers (Miranda et al., 2004).

\section{Potential Obstacles to Implementation}

Self-service checkouts can be a problematic and complicated technology to use if the consumer is unable to adapt to the new technology. Senior consumers might be less willing to use this new technology, and those consumers who were born before the introduction of self-service technology might perceive the technology as a reduction in service thereby requiring extra work on the part of the consumer. Consequently, there is negative preference to use self-service technology by the senior generation due to a lack of confidence, less human interaction and the attributes of the self-service technology (Dean, 2008).

There is always the possibility of an interruption at the hypermarket checkout station. According to Bernard (2007), interruptions at the checkout station can be due to a technical problem, organizational problem or human error. Technical problems might be due to an unreadable bar code on the product or technical jam at the checkout station. Organizational problems might be due to inappropriate layout management for consumers to checkout. Human error can be due to consumers who have forgotten to weigh certain products, such as fruits and vegetables before coming to the checkout counter. These obstacles could be reduced with a proper management strategy by hypermarket retailers. The consumer can also learn this new technology through their shopping experience.

\section{Discussion}

The overall operations in hypermarkets are expected to be smooth with a higher pace of movement through the implementation of an automatic self-checkout system. Hypermarket retailers can reduce the number of service providers or manpower if this technology is implemented. Through the use of an automatic self-checkout system, the tasks of the service provider can be changed from operating to monitoring. A single service provider can monitor between three to four checkout counters rather than working as an operator at a single checkout counter. This will definitely reduce the expenses for the hypermarket retailer. However, technology alone will not guarantee that the overall operations are successful. There is no standardized checkout counter that is the best in all aspects (Carrasco et al., 1995; Health and Safety Executive Books, 1998). Accordingly, sufficient attention should always be given to the service provider. The service provider might be low in the organization's hierarchy, but the profile is very important as per project manager in any organization. Appropriate staffing is a method for controlling the quality of service (Varca, 2004). Inappropriate staffing management at the checkout station might lead to consumer dissatisfaction, especially when the queue is long and the service is slow (Melachrinoudis \& Olafsson, 1995). Accordingly, the existence of a service provider at the checkout station is expected to enhance the existing pace of the operations by monitoring the movement flow.

Local retailers have the opportunity of learning from foreign retailers in terms of management practice and technology (Bianchi \& Mena, 2004). Petrol stations throughout Malaysia are an example of retailers that provide a $100 \%$ self-service retailing concept in which the consumer can use a credit card for the payment and fill up with petrol by themselves. In addition, the automated retailing concept has also been introduced by many other retailing companies by placing an automatic self-service technology payment kiosk, such as for parking, especially at shopping malls; payment of utility bills at Telekom Malaysia; mobile phone reloading at the service centre; purchasing transit tickets for electric trains; and the banking sector in which the transaction can be made through a kiosk by the consumer themselves. Hence, presently, it seems that there is no major problem in implementing the complete self-service concept in Malaysia. Accordingly, it is highly expected that Malaysians, especially the younger generation from urban areas, will accept similar entirely self-service concepts at hypermarket outlets. The indication of consumer readiness towards self-service technology at the hypermarket checkout station is also a reflection of the increasing level of service expectation from the hypermarket retailers. This is a typical market trend that is expected in a progressive society. Therefore, there is always an opportunity for hypermarkets to provide an innovative self-service technology to attract more millennial shoppers. This is because consumer expectations are always on the rise and hypermarket retailers must keep up to stay ahead of the market. Parallel to this, an option should always be given to the consumer who would like to be served by the service provider to cater to different needs.

\section{Conclusion}

Hypermarket retailers should 'delight' and 'surprise' consumers (Knee, 2002) by limiting consumer sovereignty 
and persuading them to act in particular ways. Instead of listening to what consumers need and desire, nowadays, retailers tend to come out with new changes that influence consumers to adapt to the modern retailing styles (Esbjerg \& Bech-Larsen, 2009). The way hypermarket retailers manage their retail operations should be according to the consumer needs (Uusitalo, 2001). Successful original ideas for retailing do not always come from the consumer but from the hypermarket retailer (Knee, 2002). As a developing country that is continuously adapting to modern technology for living, it is highly expected that Malaysian consumers will continue to welcome new technology innovation in hypermarket retailing. Hypermarket retailers should seriously consider such impending development in the retail industry.

\section{Acknowledgements}

This research project has been supported by the Multimedia University, Malaysia, through an internal research grant. Special appreciation is given to the Research Management Centre of the University for approving this research project under the Mini Fund Research 2013-2014 (Project ID: IP20130829002).

\section{References}

Bernard, S. (2007). Cashers' work-time: Between a productivity mentality and a service mentality. Sociologie $d u$ travail, 49, 129-144. http://dx.doi.org/10.1016/j.soctra.2007.10.001

Bianchi, C., \& Mena, J. (2004). Defending the local market against foreign competitors: The example of Chilean retailers. International Journal of Retail \& Distribution Management, 32(10), 495-504. http://dx.doi.org/10.1108/09590550410558635

Burt, S., \& Sparks, L. (2003). E-commerce and the retail process: A review. Journal of Retailing and Consumer Services, 10, 275-386. http://dx.doi.org/10.1016/S0969-6989(02)00062-0

Carrasco, C., Coleman, N., \& Healey, S. (1995). Packing products for customers: An ergonomics evaluation of three supermarket checkouts. Applied Ergonomics, 26(2), 101-108. http://dx.doi.org/10.1016/0003-6870(95)00007-Y

Chetthamrongchai, P., \& Davies, G. (2000). Segmenting the market for food shoppers using attitudes to shopping and to time. British Food Journal, 102(2), 81-101. http://dx.doi.org/10.1108/00070700010313071

Dean, D. H. (2008). Shopper age and the use of self-service technologies. Managing Service Quality, 18(3), 225-238. http://dx.doi.org/10.1108/09604520810871856

Diniz, C. A., \& Ferreira, M. (1998). Prevalência de sintomas músculo-esqueléticos em operadores de checkout em mercados. Revista Brasileira de Saúde Ocupacional, 25(93-94), 75-90.

Dolage, D. A. R., Sade, A. B., \& Elsadig, M. S. (2010). The influence of flexible manufacturing technology adoption on productivity of Malaysian manufacturing industry. Economic Modeling, 27, 395-403. http://dx.doi.org/10.1016/j.econmod.2009.10.005

Esbjerg, L., \& Bech-Larsen, T. (2009). The brand architecture of grocery retailers: Setting material and symbolic boundaries for consumer choice. Journal of Retailing and Consumer Services, 16, 414-423. http://dx.doi.org/10.1016/j.jretconser.2009.06.002

Hassan, H., \& Rahman, M. S. (2012). Consumer Preference on Hypermarket Brand Extension Product. Australian Journal of Basic and Applied Sciences, 6(9), 178-182.

Health and Safety Executive Books. (1998). Musculoskeletal disorders in supermarket cashiers. Physiotherapy, 84(7).

Jamieson, B. (1996). Retailing - getting it right. Nutrition \& Food Science, 4, 14-18. http://dx.doi.org/10.1108/00346659610119243

Knee, C. (2002). Learning from experience: Five challenges for retailers. International Journal of Retail \& Distribution Management, 30(11), 518-529. http://dx.doi.org/10.1108/09590550210449377

Kumar, P. (2005). The competitive impact of service process improvement: Examining customers' waiting experience in retail markets. Journal of Retailing, 81, 171-180. http://dx.doi.org/10.1016/j.jretai.2005.07.002

Larson, P. D., \& Sijbrands, M. J. C. (1991). Quick response retailing in Canada and the Netherlands. International Journal of Retail and Distribution Management, 19(7), 10-17. http://dx.doi.org/10.1108/EUM0000000002956

Mantrala, M. K., Levy, M., Kahn, B. E., Fox, E. J., Gaidarev, P., Dankworth, B., \& Shah, D. (2009). Why is 
assortment planning so difficult for retailers? A framework and research agenda. Journal of Retailing, 85, 71-83. http://dx.doi.org/10.1016/j.jretai.2008.11.006

Mascarenhas, O. A., Kesavan, R., \& Bernacchi, M. (2004). Customer value-chain involvement for co-creating customer delight. Journal of Consumer Marketing, 21(7), 486-496. http://dx.doi.org/10.1108/07363760410568707

Melachrinoudis, E., \& Olafsson, M. (1995). A microcomputer cashier scheduling system for supermarket stores. International Journal of Physical Distribution \& Logistics Management, 25(1), 34-50. http://dx.doi.org/10.1108/09600039510080180

Meuter, M., Ostrom, A., Roundtree, R., \& Bitner, M. (2000). Self-service technologies: Understanding customer satisfaction with technology-based service encounters. Journal of Marketing, 64, 50-64. http://dx.doi.org/10.1509/jmkg.64.3.50.18024

Miranda, M. J., Konya, L., \& Havrila, I. (2004). Are non-itemized purchase receipts issued by stores without price scanners a concern for Australian shoppers? International Journal of Retail \& Distribution Management, 32(4), 216-222. http://dx.doi.org/10.1108/09590550410528980

Rajamma, R. K., Paswan, A. K., \& Hossain, M. M. (2009). Why do shoppers abandon shopping cart? Perceived waiting time, risk, and transaction inconvenience. Journal of Product \& Brand Management, 18(3), 188-197. http://dx.doi.org/10.1108/10610420910957816

Rodacki, A. L. F., Vieira, J. E. A., Okimoto, M. L. L. R., Fowler, N. E., \& Rodacki, C. L. N. (2006). The effect of handling products of different weights on trunk kinematics of supermarket cashiers. International Journal of Industrial Ergonomics, 36, 129-134. http://dx.doi.org/10.1016/j.ergon.2005.09.002

Schermerhorn, J. R. (2002). Management (7th ed.). John Wiley \& Son, Inc.

Shinnar, A., Indelicato, J., Altimari, M., \& Shinnar, S. (2004). Survey of ergonomic features of supermarket cash registers. International Journal of Industrial Ergonomics, 34, 535-541. http://dx.doi.org/10.1016/j.ergon.2004.05.007

Sluchak, T. J. (1991). Ergonomic challenges in supermarket front-end workstations. Proceedings of the Human Factors Society 35th Annual Meeting, 862-866.

Uusitalo, O. (2001). Consumer perceptions of grocery retail formats and brands. International Journal of Retail \& Distribution Management, 29(5), 214-225. http://dx.doi.org/10.1108/09590550110390995

Varca, P. E. (2004). Service skills for service workers: emotional intelligence and beyond. Managing Service Quality, 14(6), 457-467. http://dx.doi.org/10.1108/09604520410569793

Walker, R., \& Johnson, L. (2006). Why consumers use and do not use technology-enabled services. Journal of Services Marketing, 20(2), 125-135. http://dx.doi.org/10.1108/08876040610657057

Zhao, X., Lau, R. S. M., \& Lam, K. (2002). Optimizing the service configuration with the least total cost approach. International Journal of Service Industry Management, 13(4), 348-361. http://dx.doi.org/10.1108/09564230210445050

\section{Copyrights}

Copyright for this article is retained by the author(s), with first publication rights granted to the journal.

This is an open-access article distributed under the terms and conditions of the Creative Commons Attribution license (http://creativecommons.org/licenses/by/3.0/). 